\author{
Alina Walenia \\ University of Rzeszów \\ Faculty of Economics \\ Department of Economic Policy \\ e-mail: alinawalenia@poczta.onet.pl
}

\title{
Deontologiczne zasady dobrej administracji w dokumentach UE Uwagi o ich wdrażaniu w Polsce
}

\section{Deontological principles of good administration in EU documents Comments on their implementation in Poland}

The proper functioning of local-government administration means not only improving legal and organisational solutions, but mainly officials abiding by ethical principles. Therefore, an important role in the process is played by the ethical standards of good administration referred to in the European Code of Good Administrative Behaviour. The principles apply to the assessment of the operation of public administration. They reflect the duties of the administration towards the citizens. The purpose of this paper is to assess the importance of the principles of ethics as a factor conditioning the efficient operation of local government administration. The questionnaire research carried out among local government staff and their stakeholders enabled the identification of the most frequent irregularities in the work of the officials and indicates the importance of the principles of ethics in the process of eliminating irregularities.

Keywords: principles of ethics in local government administration, European Code of Good Administrative Behaviour

JEL Classification: M40, M41, M49 


\section{Wprowadzenie}

Prawidłowe funkcjonowanie administracji samorządowej zapewnia nie tylko doskonalenie rozwiązań prawnych, organizacyjnych, ale przede wszystkim przestrzeganie przez urzędników zasad etycznych. Dlatego istotną rolę w tym procesie odgrywają standardy etyczne dobrej administracji wskazane w Europejskim Kodeksie Dobrej Administracji. Zasady te mają także zastosowanie do oceny funkcjonowania administracji publicznej. Wskazują obowiązki administracji wobec obywateli. Celem artykułu jest ocena znaczenia zasad etyki jako czynnika warunkującego sprawność funkcjonowania administracji samorządowej. Badania ankietowe przeprowadzone wśród pracowników urzędów samorządowych i ich interesariuszy pozwoliły zidentyfikować najczęściej występujące nieprawidłowości w pracy urzędników oraz wskazać znaczenie zasad etyki w procesie ich eliminowania.

Karta Praw Podstawowych Unii Europejskiej (KPPUE), przyjęta w grudniu 2000 r. w Nicei, zawiera w katalogu praw m.in. prawo do dobrej administracji (art. 41). Oznacza to, że podstawowym prawem każdego obywatela Unii Europejskiej (UE) jest prawo do bezstronnego, legalnego i bez zbędnej zwłoki rozpatrzenia sprawy wniesionej do organów i instytucji w państwach członkowskich i w UE. Zgodnie z zapisami KPPUE organy i instytucje państwa, a także zatrudnieni $\mathrm{w}$ nich pracownicy mają obowiązek właściwego, zgodnego $\mathrm{z}$ prawem załatwienia spraw zgłaszanych przez obywateli. KPPUE wskazuje także na możliwości dochodzenia roszczenia o odszkodowanie w przypadku, gdy w wyniku działań administracji publicznej wnoszący sprawę poniósł szkodę.

Konkretyzacją obywatelskiego prawa do dobrej administracji unijnej i narodowej $\mathrm{w}$ poszczególnych państwach członkowskich, wyrażonego w art. 41 KPPUE, jest uchwalony 6 września 2001 r. przez Parlament Europejski Kodeks Dobrej Praktyki Administracyjnej (EKDA). Dokument ten jest niewiążącym aktem prawnym, mającym charakter zaleceń. Zasady zapisane w EKDA dotyczą etyki i etosu zawodowego urzędnika i odnoszą się do wszystkich postępowań administracyjnych. Wskazują na konieczność zachowania prawidłowych relacji pomiędzy instytucjami/urzędnikami unijnymi a jednostkami (osobami fizycznymi i prawnymi). Zasady te dotyczą nie tylko spraw indywidualnych z zakresu administracji publicznej, załatwianych w drodze decyzji, postanowienia lub ugody administracyjnej, ale każdego kontaktu z administracją (a więc także zapytań, petycji, protestów, przedstawiania uwag do projektów aktów prawnych, obywatelskich projektów dyrektyw itp.).

EKDA jest dokumentem zasługującym na uznanie, mogącym przyczynić się do lepszego działania organów administracji oraz stanowić gwarancję skuteczniejszej ochrony praw obywateli $\mathrm{i}$ innych podmiotów $\mathrm{w}$ relacjach $\mathrm{z}$ organami UE i państw członkowskich. Dokument ten stanowi zbiór standardów mających zastosowanie do oceny funkcjonowania administracji w UE i w poszczególnych państwach członkowskich. Standardy te są podstawą do wyznaczania obowiązków polskiej administracji w codziennych kontaktach obywateli z urzędem i ich dosto- 
sowania do wymogów stawianych w Unii Europejskiej. Kodeks Dobrej Administracji może być także przydatny dla polskiego obywatela, ponieważ pozwoli na lepszą ochronę i realizację podstawowego prawa do dobrej administracji. Przestrzeganie zasad przyczyni się do podniesienia poziomu pracy administracji, szczególnie samorządowej, w kontaktach z obywatelem i jego sprawami.

Prawidłowe funkcjonowanie administracji samorządowej wymaga ciągłego doskonalenia rozwiązań prawnych i organizacyjnych. W związku z powyższym celem artykułu jest wskazanie czynników warunkujących dobre funkcjonowanie administracji samorządowej, czyli poza zasadą praworządności także zasad etyki określonych w EKDA. Analiza czynników warunkujących sprawność funkcjonowania urzędów samorządowych, tj. wykonywania zadań publicznych na rzecz obywateli, dokonana została w oparciu o wyniki badań ankietowych przeprowadzonych wśród mieszkańców wspólnot samorządowych korzystających z usług publicznych, a także pośród pracowników świadczących te usługi. Ankietowani klienci wskazywali na niepoprawne zachowania urzędników samorządowych. Pracownicy samorządowi natomiast wskazywali najczęściej występujące przyczyny nierzetelnego wykonywania zadań publicznych.

\section{Katalog podstawowych zasad dobrej administracji określonych w dokumentach UE}

EKDA jest dokumentem, który powinien przyczynić się do podniesienia poziomu pracy urzędników i wzmocnienia ochrony prawa do dobrej administracji. Kodeks uwzględnia zasady obowiązujące w prawie UE, nie stanowi jednak aktu prawnie wiążącego, ma jedynie charakter zaleceń. Dokument ten nie zawiera przepisów, które byłyby nieznane $\mathrm{w}$ dotychczasowych regulacjach europejskich i w wewnętrznych porządkach prawnych państw członkowskich UE (Modzelewski, 2012). Stosowanie zasad zawartych w EKDA wpłynie na poprawę pracy urzędników, szczególnie w kontaktach z obywatelami i ich sprawami. Ponadto zastosowanie standardów zawartych w EKDA pozwoli na ,przystosowanie codziennych kontaktów obywatela z urzędem do wymogów stawianych w UE”, a obszar ten ciągle wzbudza wątpliwości. Urzędnicy powinni kierować się nie tylko obowiązującymi normami prawa, ale także uwzględniać zasady etyki i etosu zawodowego. W tym ujęciu EKDA stanowi istotny czynnik prawa jednostki do dobrej administracji, ponieważ kreuje pozytywny wizerunek funkcjonariusza publicznego, między innymi po to, aby zyskał on akceptację w ocenie opinii publicznej (Czajka, 2012). Przedstawiając powyższe uwarunkowania, warto dokonać skrótowego przeglądu treści EKDA, mimo że nie stanowi on ius cogens w polskim porządku prawnym. Przepisy EKDA odnoszą się do działań funkcjonariuszy, organów i instytucji Unii Europejskiej w stosunkach z podmiotami zewnętrznymi. Dokument wskazuje 27 zasad, które są szczególnie ważne w funkcjonowaniu administracji publicznej, zawierających ogólne wskazania dotyczące postępowania administracyjnego i stanowi podstawę do uregulowań zawartych w polskich postępo- 
waniach administracyjnych (w KPA - 269 artykułów, w postępowaniu podatkowym - 291).

Regulacje kodeksowe wyrażają podstawowe cele i zasady wyznaczające kierunki działań administracji, a także zalecenia techniczno-procesowe. Podstawowe zasady dobrej administracji wskazują na następujące wartości etyczne: praworządność, niedyskryminacja i równe traktowanie, proporcjonalność, niezawodność i stabilność, profesjonalizm i zawodowa uczciwość. Kierując się natomiast systematyką EKDA, można wyróżnić następujące zasady:

Zasada praworządności (art. 4) nakazuje organom i funkcjonariuszom działanie zgodne $\mathrm{z}$ obowiązującym materialnym i procesowym prawem Unii Europejskiej oraz rozstrzyganie spraw indywidualnych w oparciu o odpowiednią podstawę prawną.

Zasada niedyskryminacji i równego traktowania (art. 5) zobowiązuje urzędników do powstrzymania się od nieusprawiedliwionego nierównego traktowania osób ze względu na narodowość, płeć, rasę, kolor skóry, pochodzenie etniczne lub społeczne, język, religię lub wyznanie, poglądy polityczne lub inne, przynależność do mniejszości narodowej, posiadaną własność, urodzenie, inwalidztwo, wiek i preferencje seksualne; wszelkie nierówne traktowanie musi być obiektywnie uzasadnione.

Zasada współmierności (art. 6) wymaga od urzędnika podejmowania działań współmiernych do osiągnięcia obranego celu bez zbędnego ograniczania praw lub nakładania nadmiernych obowiązków na obywateli, mając przy tym na uwadze stosowne wyważenie interesu indywidualnego i interesu publicznego.

Zakaz nadużywania władzy publicznej w innym celu niż została powierzona (art. 7) wskazuje, aby cel podjętych działań wynikał z określonej podstawy prawnej lub interesu publicznego, w przeciwnym przypadku postępowanie urzędnika kwalifikuje się jako nadużycie uprawnień i może skutkować pociągnięciem go do odpowiedzialności. Realizacja tej zasady nawiązuje do wcześniej wskazanych zasad praworządności i współmierności.

Zasada bezstronności i niezależności (art. 8) nakazuje urzędnikom powstrzymanie się od wszelkich form faworyzowania i arbitralnych działań, a także nieuwzględniania przy rozstrzyganiu spraw własnego interesu osobistego, rodzinnego, narodowego, interesu politycznego. Zasada zawiera postulat, aby urzędnik podlegał wyłączeniu od załatwiania spraw, w których on sam lub bliski członek jego rodziny miałby interes majątkowy.

Zasada obiektywności (art. 9) wymaga, aby urzędnik przy rozstrzyganiu sprawy nie sugerował się okolicznościami z tą sprawą niezwiązanymi, a jedynie uwzględniał istotne okoliczności i fakty oraz należycie oceniał ich znaczenie.

Zasada stabilności i doradztwa oraz uwzględniania słusznego interesu jednostki (art. 10) nakazuje urzędnikom konsekwentne przestrzeganie reguł dotychczas ukształtowanej praktyki administracyjnej, a wszelkie uzasad- 
nione odstępstwa od tej praktyki muszą zostać umotywowane pisemnie, ponadto $\mathrm{w}$ razie potrzeby urzędnik udziela jednostce porad co do sposobu postępowania przy załatwieniu sprawy.

Zasada uczciwości i rozsądnego działania (art. 11) - kodeks nie rozwija treści tej zasady, ale przyjmuje się, że w wyniku przestrzegania wszystkich pozostałych zaleceń działanie urzędnika będzie uczciwe i rozsądne.

Zasada uprzejmości (art. 12) zaleca, aby zachowanie urzędnika było właściwe, przystępne i uprzejme zgodnie z przyjętym modelem francuskiej służby publicznej (service publique), akcentującej usługodawczą rolę funkcjonariuszy administracji. Urzędnik, odpowiadając na korespondencję, telefony i e-maile, powinien wyczerpująco i dokładnie wyjaśnić wszystkie kwestie, o które jest pytany, dodatkowo być jak najbardziej pomocny. W przypadku popełnienia błędu naruszającego prawa lub interes jednostki urzędnik winien przeprosić i skorygować negatywne skutki w najwłaściwszy sposób. Realizacja tej zasady wynika nie tylko ze służebnej roli administracji publicznej, ale przede wszystkim wymaga wysokiej kultury osobistej urzędnika. Na podkreślenie zasługuje fakt, że obecnie wiele osób czuje się zagubionych w gąszczu przepisów prawnych, które są często zmieniane, a do tego mało komunikatywne, trudne do interpretacji, wobec czego niezbędne staje się życzliwe informowanie interesantów o stanie prawnym i przysługujących im w danej sprawie uprawnieniach.

Zasada odpowiadania na pisma w języku obywatela (art. 13) ma zastosowanie do każdego pisma wniesionego przez obywatela Unii Europejskiej, ponadto zaleca się $\mathrm{w}$ miarę możliwości stosowanie tej zasady do pism kierowanych do instytucji i organów UE przez osoby prawne, organizacje pozarządowe i przedsiębiorców.

Zasada potwierdzania odbioru pism (art. 14) wymaga od urzędnika zachowania dwutygodniowego terminu potwierdzania wniesienia pisma do organów i instytucji UE, z wyjątkiem sytuacji, gdy w tym terminie zostanie przekazana odpowiedź na pismo wraz z merytorycznym uzasadnieniem (istotne jest, że każde potwierdzenie odbioru winno zawierać nazwisko, stanowisko służbowe i numer telefonu pracownika zajmującego się daną sprawą).Urzędnik nie ma natomiast obowiązku potwierdzania pism wnoszonych w nadmiernej liczbie lub pism zawierających bezsensowną treść.

Zasada przekazywania sprawy do właściwej jednostki organizacyjnej instytucji (art. 15) znajduje zastosowanie w przypadku skierowania pisma do organu czy instytucji niewłaściwej w danej sprawie. Urzędnik ma za zadanie ustalenie oraz przekazanie pisma według właściwości i niezwłocznego poinformowania o dokonanej czynności wnoszącego pismo wraz z podaniem nazwiska, stanowiska służbowego i numeru telefonu osoby, do której akta zostały skierowane. Urzędnik obowiązany jest wskazać ewentualne braki oraz błędy w dokumentach i umożliwić wnoszącemu uzupełnienie ich lub skorygowanie. 
Zasada wysłuchania jednostki (art. 16) umożliwia osobie realizację prawa do obrony poprzez udział $\mathrm{w}$ każdym stadium postępowania, a przed jego zakończeniem uprawnia do przekazania ewentualnych zastrzeżeń wyrażonych w formie ustnej lub pisemnej.

Zasada przestrzegania terminowości załatwienia sprawy (art. 17) zaleca, aby każde pismo (wniosek, zażalenie) zostało rozpatrzone niezwłocznie, a w przypadku trudności nie później niż w terminie dwóch miesięcy od daty jego wniesienia; w sytuacji niezachowania terminu załatwienia skomplikowanej sprawy urzędnik winien poinformować wnoszącego o nowym, jak najszybszym terminie zakończenia postępowania.

Zasada obowiązkowego uzasadniania decyzji (art. 18) wymaga merytorycznego wyjaśnienia rozstrzygnięcia sprawy z przytoczeniem istotnych faktów i podstawy prawnej wydanej decyzji, ale tylko w odniesieniu do rozstrzygnięcia negatywnie wpływającego na prawa lub interes jednostki. W sytuacji wydawania dużej liczby podobnych decyzji dopuszczalne jest przekazywanie standardowych odpowiedzi, a szczegółowe uzasadnianie tych spraw odbywać się powinno tylko na wyraźne żądanie adresata decyzji. Przewiduje się możliwość odstąpienia od rozstrzygania ze względu na brak wyraźnej i wystarczającej podstawy prawnej do wydania decyzji w określonej sprawie.

Zasada pouczania o możliwościach odwołania (art. 19) - urzędnik zobowiązany jest do poinformowania o możliwości wniesienia odwołania od decyzji z podaniem przysługujących środków zaskarżenia i terminu ich przedłożenia; w szczególności powiadomienia o możliwości skorzystania z drogi sądowej oraz złożenia skargi do Rzecznika Praw Obywatelskich UE.

Zasada niezwłocznego doręczania podjętych rozstrzygnięć (art. 20) - natychmiast po podjęciu decyzji urzędnik zapewnia przekazanie ich treści adresatowi, a dopiero potem powiadamia o postanowieniu inne osoby zainteresowane danym rozstrzygnięciem.

Zasada ochrony danych (art. 21) - urzędnik przy wykorzystywaniu i przetwarzaniu danych osobowych jednostki musi uwzględniać sferę prywatności oraz nietykalności osobistej, zgodnie $\mathrm{z}$ obowiązującym w tym zakresie rozporządzeniem Parlamentu Europejskiego i Rady (UE) 2016/679. Zasada wprowadza również zakaz przekazywania i ujawniania danych osobom nieuprawnionym lub innego ich bezprawnego wykorzystania.

Zasada udzielania informacji w jasny i zrozumiały sposób (art. 22) - jednostki mogą kierować do organów i instytucji UE wnioski o informacje w formie ustnej, a przy składaniu skomplikowanych lub obszernych zapytań w formie pisemnej. Urzędnik ma obowiązek udzielić odpowiedzi w jasny i zrozumiały sposób, nie może natomiast ujawniać informacji poufnych. Jeżeli urzędnik nie jest właściwy do udzielenia żądanej informacji, przekazuje wniosek według właściwości oraz zawiadamiania o tym fakcie wnoszącego (podając nazwisko i numer telefonu urzędnika 
właściwego w sprawie). Tylko w uzasadnionych przypadkach możliwe jest skierowanie osoby żądającej informacji do odpowiedniej jednostki organizacyjnej odpowiedzialnej za udzielanie informacji obywatelowi.

Zasada prowadzenia rejestrów (art. 23) - poszczególne wydziały instytucji muszą prowadzić rejestry poczty przychodzącej i wychodzącej oraz innych przekazywanych im dokumentów.

\section{Znaczenie zasad etyki określonych w Europejskim Kodeksie Dobrej Administracji w polskich warunkach}

Pracę w administracji samorządowej regulują akty prawa, one też określają sposób obsługi klienta i mają wpływ na projektowanie procedur. Jej nadrzędnym celem jest służba innym, zawsze przy uwzględnieniu priorytetowej wartości, jaką jest dobro publiczne. Specyficzny charakter mają także relacje z klientami - obywatelami, którym przysługuje prawo kontroli i partycypacji społecznej. Mieszkańcy $\mathrm{z}$ mocy prawa tworzą wspólnotę samorządową. Występują w roli klienta usług publicznych, ale także mają możliwość wpływu na procesy decyzyjne, pełnią też funkcję wyborcy, podatnika i konsumenta usług.

Kodeks Dobrej Administracji stanowi, że organ administracji publicznej ma obowiązek załatwienia sprawy zgodnie ze słusznym interesem obywatela, działając jednocześnie w zgodzie z prawem oraz własnymi kompetencjami. Jego rdzeń stanowi pięć zasad: praworządności, niedyskryminowania, współmierności, obiektywności, konsekwentnego i zgodnego z oczekiwaniami działania. Ponadto urzędnicy mogą przyjmować w pracy różne postawy, które zależą od ich cech charakteru i celów, jakie sobie stawiają:

(1) postawa społecznej dyscypliny - cechuje ją umiejętność podporządkowania się np. własnym postanowieniom czy poleceniom osób kierujących pracą oraz świadomość konieczności istnienia norm regulujących zachowanie i gotowość do ich przestrzegania w życiu społecznym;

(2) postawa społecznej użyteczności (,nie bierz więcej, niż dajesz”) - gotowość do inicjatywy i twórczego działania, umiejętność oceniania pracy własnej i innych, odczuwanie zadowolenia i satysfakcji z pracy własnej i na rzecz zespołu, w którym się pracuje;

(3) postawa społecznej gospodarności - świadomość trudu zawartego w rezultatach pracy ludzkiej oraz racjonalne gospodarowanie majątkiem własnym czy organizacji; takiego urzędnika charakteryzuje oszczędność i efektywność, a także szacunek do własności innych osób i tzw. własności wspólnej;

(4) postawa społecznego zaangażowania - pełnienie ról społecznych w życiu zawodowym, wrażliwość na problemy zespołu oraz czynne uczestnictwo w życiu zespołu;

(5) postawa społecznej otwartości - umiejętność sprawiedliwego oceniania niezależnie od osoby, jednakowe traktowanie innych ludzi i zespołów; 
(6) postawa zespołowości - dbałość o dobre stosunki z tymi, z którymi wypadło nam współpracować, o odpowiednią atmosferę współpracy, lojalność, szacunek dla odmiennych przekonań i poglądów.

Urzędnik, który powierzone mu zadania wykonuje rzetelnie i w zgodzie z zasadami moralnymi, zawsze postrzegany jest przez obywatela jako ten, który stoi na straży praworządności. To on jest siłą napędową administracji i to za jego sprawą działania administracyjne realizowane są sprawnie, fachowo, rzetelnie i sprawiedliwie. Osoba, która postępuje zgodnie z etyką zawodową, jest świadoma zobowiązań wynikających z posiadanej wiedzy, a także skutków swej działalności. Analizując powyższą problematykę, można stwierdzić, że aby służba cywilna była elementem funkcjonowania publicznych instytucji, konieczne jest etyczne i fachowe wykształcenie kadry urzędniczej. Bez osób kompetentnych, działających w zgodzie z prawem i normami moralnymi, bez wiarygodnej i sprawnej służby publicznej nie można mówić o demokratycznym państwie. Dlatego zasady EKDA powinny być podstawowym instrumentem służącym budowaniu przejrzystej, efektywnej i kompetentnej administracji publicznej, działającej w zgodzie z prawem i służącej obywatelom.

Administracja, w tym także samorządowa, musi podlegać procesowi stałego reformowania. Zmiany te powinny zmierzać do wypracowania nowego modelu administracji zarządzającej, przedsiębiorczej, ukierunkowanej na współpracę z partnerami społeczno- gospodarczymi i działającej efektywnie oraz zawsze mającej na uwadze dobro publiczne. Dostrzegając potrzebę budowy etosu służby publicznej, wydane zostało zarządzenie nr 70 Prezesa Rady Ministrów z dnia 6 października 2011 r. w sprawie wytycznych przestrzegania zasad służby cywilnej oraz w sprawie zasad etyki korpusu służby cywilnej. Zarządzenie określa standardy postępowania pracowników sektora publicznego, którzy powinni być bezstronni podczas wykonywania służbowych zadań i obowiązków. Zapisy cytowanego zarządzenia stanowią między innymi o zasadach:

(1) godnego zachowania - życzliwości w stosunku do ludzi oraz zapobieganiu konfliktom w pracy, w relacjach ze współpracownikami czy obywatelami. Zasada godnego zachowania wyraża się przede wszystkim poprzez realizację pracy $\mathrm{z}$ zachowaniem szacunku dla reguł kultury osobistej, współżycia społecznego i poszanowania godności innych (przełożonych, kolegów i podwładnych);

(2) służby publicznej - podkreślającej służebny charakter pracy wobec obywateli. Jej istotą są: służba państwu, wpływ na postrzeganie Rzeczypospolitej Polskiej w kraju i w UE oraz współtworzenie wizerunku służby cywilnej. Zasada służby publicznej przejawia się również w przedkładaniu dobra publicznego ponad interesy własne, jednostkowe czy grupowe, dzięki czemu sprawy administracyjne załatwiane są z uwzględnieniem zasad etyki;

(3) lojalności - gotowości do realizacji służbowych poleceń, lojalności wobec Rzeczypospolitej Polskiej, urzędu, przełożonych, podwładnych i kolegów. Zasada ta obejmuje także udzielanie przełożonym obiektywnych opinii i porad, a także zachowywanie powściągliwości w wypowiadaniu 
publicznie poglądów dotyczących pracy swojego urzędu i innych urzędów;

(4) neutralności politycznej - rzetelnego i lojalnego realizowania programu rządowego, bez względu na własne poglądy polityczne i przekonania. Przejawia się poprzez: odrzucenie nacisków politycznych i wpływów; niemanifestowanie poglądów i sympatii politycznych publicznie, niepodejmowanie agitacji politycznych, nieangażowanie się w publiczne akcje, które bezpośrednio wspierają działalność o charakterze politycznym. Urzędnik samorządowy nie może stwarzać podejrzeń o sprzyjanie partiom politycznym, powinien dbać o przejrzystość relacji z osobami pełniącymi funkcje polityczne;

(5) rzetelności - odpowiedzialności, jak najlepszej woli, sumienności i aktywności w wykonywaniu obowiązków członka służby cywilnej. To także dotrzymywanie zobowiązań, kierowanie się prawem oraz działanie w interesie społecznym, bez ograniczania się jedynie do przestrzegania obowiązujących przepisów.

Przepisy EKDA mają na celu przeciwdziałanie zjawiskom nadużywania władzy w sytuacji, gdy regulacje prawne nie zawierają wyraźnych wytycznych co do rozstrzygnięcia poszczególnych spraw. Kodeks stanowi, że organ administracji publicznej ma obowiązek załatwienia sprawy zgodnie ze słusznym interesem obywatela, działając jednocześnie w zgodzie z prawem oraz własnymi kompetencjami. Dobra administracja stanowi dyrektywę mającą zapewnić efektywne funkcjonowanie organów administracji i oznacza nie tylko działania administracji zgodne z prawem, ale takie zachowanie urzędników, które uznać można za bezstronne, obiektywne, niepodlegające wpływom politycznym ani partykularnym interesom (Kowalczyk, 2008). Natomiast prawo do dobrej administracji stanowi prawo podmiotowe, czyli prawo jednostki do żądania określonych uprawnień i zachowań urzędników.

\section{Identyfikacja najczęściej występujących nieetycznych zachowań w pracy urzędników samorządowych: wyniki badań ankietowych}

W pracę urzędnika wpisana jest konieczność podejmowania decyzji, często o złożonym charakterze, w sytuacjach, gdy prawo w sposób jasny i klarowny nie wskazuje określonych rozwiązań albo też ustawodawca nie był w stanie przewidzieć wszystkich sytuacji, jakie niesie codzienność. Działalność administracji samorządowej musi uwzględniać zbiór wartości moralnych, których wspólnym mianownikiem jest uczciwość wobec siebie, współpracowników i obywateli. Postawy, decyzje i zachowania urzędników podlegają ocenom, w tym także moralnym. Skutki ich decyzji mogą wywierać wpływ na wielu ludzi, a sposoby administrowania i jego efekty nie są moralnie obojętne, mogą powodować cierpienie, krzywdy i niesprawiedliwość. W pracy urzędnika nie może obowiązywać 
całkowita dowolność i swoboda. Samodzielność działań ograniczona jest kryteriami prawnymi oraz pozaprawnymi - wynikającymi z zasad współtworzenia i realizacji polityki administracyjnej, zasad organizacji pracy urzędu i zasad profesjonalnego wykonywania zawodu. Urzędnicy w demokratycznym społeczeństwie mają kompetencje i określony zakres prawnych możliwości do projektowania i planowania polityki administracyjnej, wyboru postępowania i sposobu jej realizacji (Bugdol, 2008, s. 145-146). W związku z powyższym pracownik administracji publicznej, w tym także samorządowej, powinien postępować zgodnie z przyjętymi zasadami etycznymi i z wykorzystaniem tych zasad rozumieć znaczenie pełnionej roli społecznej. Powinien także posiadać dobrą znajomość zasad etyki zawodowej urzędnika, kultury administrowania oraz norm i wartości wynikających z kultury organizacyjnej. Za niezbędne należy uznać prezentowanie postawy, na którą składają się: twórcze i społeczne zaangażowanie, szacunek do pracy, społeczna przydatność, gospodarność, dyscyplina, odpowiedzialność, otwartość, umiejętność samokontroli, poszanowanie godności człowieka. Kanon profesjonalnego urzędnika powinny tworzyć takie elementy, jak: obiektywizm, odpowiedzialność, neutralność polityczna, prawne umocowanie działań i decyzji, racjonalność działań, jawność oraz otwartość procedur i decyzji, precyzja i poprawność sformułowań, drożność kanałów informacji i ich kompletność oraz etyka postępowania.

Obowiązki urzędnika samorządowego wynikające $\mathrm{z}$ charakteru pracy w administracji można podzielić na trzy kategorie:

(1) obowiązki wobec państwa - przestrzeganie Konstytucji RP i innych przepisów prawa, zaangażowanie w realizację celów polityki państwa, podejmowanie w jego imieniu działań i decyzji;

(2) obowiązki wobec społeczeństwa - urzędnik jest zobowiązany chronić prawa i interesy obywateli, kierować się zasadami demokracji, reagować na uwagi, wnioski i skargi obywateli dotyczące instytucji państwowych, analizować postulaty społeczeństwa, działać sprawnie i bezstronnie;

(3) obowiązki wobec urzędu - urzędnik powinien wykonywać swoje obowiązki w sposób zapewniający sprawną i prawidłową realizację zadań urzędu, a więc sumiennie, solidnie i starannie wypełniać zadania na stanowisku pracy, wykazywać zdolność myślenia systemowego, postrzegać urząd jako całość oraz podejmować inicjatywy usprawniające jego funkcjonowanie, doskonalące metody pracy i organizację wewnętrzną. Niezbędne jest także przestrzeganie dyscypliny pracy, podnoszenie kwalifikacji, dbałość o dobrą opinię urzędu.

Celem przeprowadzonych badań ankietowych ${ }^{1}$ była weryfikacja przestrzegania przez urzędników samorządowych wymienionych wyżej zasad postępowania

\footnotetext{
1 W badaniu ankietowym, przeprowadzonym w 2017 roku, kwestionariusz badawczy wypełniło 150 osób będących klientami jednostek administracji samorządowej województwa podkarpackiego oraz 50 pracowników samorządowych zatrudnionych w 10 jednostkach administracji samorządowej zlokalizowanych w tym regionie. Ankieta miała charakter pytań otwartych. Respondenci dobrani zostali do badań w sposób przypadkowy bez wyszczególnienia wieku, płci, wykształcenia. Zastosowana technika badawcza miała koncentrować się na ocenie badanego zjawiska, tj. obszarów nieetycznych zachowań urzędników i ich przyczyn.
} 
w służbie publicznej. Wyniki badań pozwoliły na wskazanie najczęściej występujących nieetycznych zachowań urzędników samorządowych w związku z wykonywaniem zadań na rzecz mieszkańców wspólnoty samorządowej. Ocena postaw moralnych pracowników samorządowych przeprowadzona została po ponad dwudziestu latach funkcjonowania samorządu terytorialnego w Polsce. Najczęściej występujące nieprawidłowości w pracy urzędników samorządowych wynikały głównie z nieprzestrzegania zasad etyki urzędnika. Niezgodne z postanowieniami EKDA zachowania pracowników samorządowych (rys. 1) dotyczyły przede wszystkim nierzetelności i niedokładności. Na powyższą nieprawidłowość wskazywało ok. 80\% ankietowanych klientów urzędów samorządowych. Kolejną nieprawidłowością podnoszoną przez interesariuszy urzędów samorządowych był nieodpowiedni sposób obsługi (64\%), np. nieodpowiednie zachowanie urzędnika wobec klienta. Wykorzystywanie przez urzędnika swojej pozycji do osiągnięcia korzyści osobistych podnosiło ok. 45\% ankietowanych, a brak wiedzy i kompetencji w zakresie wykonywanych zadań - 10\%. Niedociągnięcia dotyczyły także sposobu wykonywania zadań przez urzędnika, czyli popełniania błędów, a także nieodpowiedniego zachowania (64\%). Ponad 80\% klientów wskazało na niewłaściwy dobór kandydatów na stanowiska urzędnicze, podkreślając, że ocena moralna kandydata powinna być ważna w procesie aplikacji. Potwierdza to oczekiwania społeczeństwa wobec tej grupy zawodowej. Ankietowani podnosili, że wiedza i przygotowanie merytoryczne są możliwe do uzyskania, a wypracowane zasady moralne trudne do osiągnięcia. Dostrzegali oni wyraźną zależność pomiędzy postawą moralną a jakością pracy.

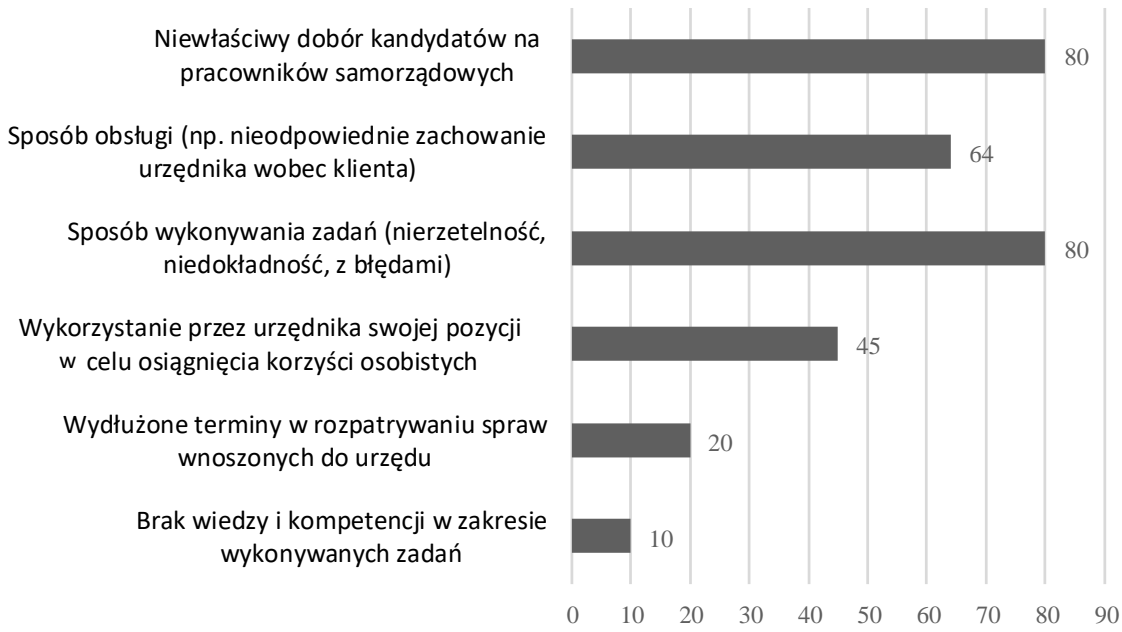

Rys. 1. Najczęściej występujące nieetyczne zachowania urzędników samorządowych w zakresie wykonywania zadań - w ocenie klientów (w \%) 
Ankietowani pracownicy dokonywali oceny jakości wykonywanej przez siebie pracy. Obszar ten wpisuje się w oczekiwania klientów usług publicznych. Jakość usług publicznych podniesiona została jako jeden z głównych celów strategicznych funkcjonowania urzędów państwowych stanowiący istotny czynnik warunkujący satysfakcję klienta. W ocenie pracowników samorządowych (rys. 2) najwięcej zastrzeżeń budziły zakres i formy delegowania przez kierownictwo zadań oraz sposób ich wykonywania przez urzędników (30\%). Na nieprawidłowe funkcjonowanie administracji samorządowej istotny wpływ miał brak współpracy pomiędzy pracownikami $(19 \%)$ oraz pomiędzy przełożonymi a pracownikami $(21 \%)$.

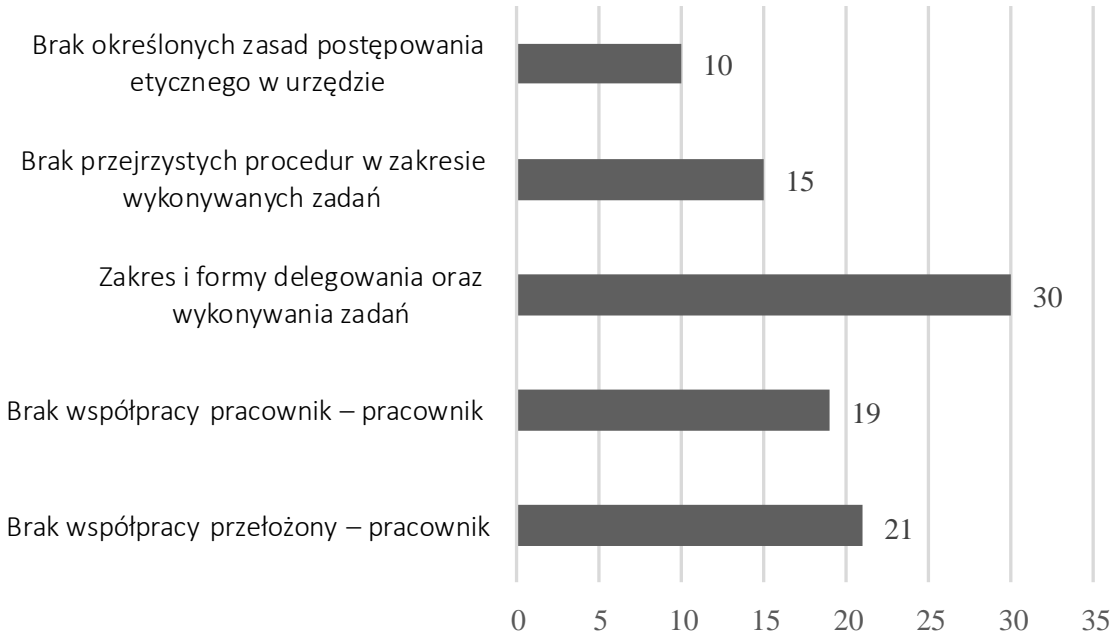

Rys. 2. Najczęściej występujące przyczyny nieetycznego zachowania urzędników samorządowych w związku z wykonywaniem zadań wedle ich własnej oceny (w \%)

Na pytanie, jakie czynniki wywierały największy wpływ na nieetyczne zachowania urzędników samorządowych w zakresie wykonywania zadań publicznych, czyli nieprzestrzeganie zasad etyki i etosu urzędnika wynikających z EKDA, zdecydowana większość ankietowanych pracowników odpowiedziała, że $\mathrm{w}$ procesie aplikacji na stanowisko $\mathrm{w}$ administracji samorządowej postawa moralna kandydata powinna być poddana szczególnie wnikliwej ocenie (rys. 3). Innu czynnik, który sprzyjają nieprawidłowościom w funkcjonowaniu administracji samorządowej, to m.in. nieodpowiednie delegowanie zadań dla poszczególnych pracowników polegające na zbyt szerokim ich zakresie oraz braku specjalizacji (70\%). Kolejne istotne czynniki, podnoszone przez ankietowanych, to mało skuteczne metody motywowania pracowników w procesie zarządzania zasobami w samorządzie terytorialnym $(50 \%)$, a także brak wypracowanych obiektywnych metod oceny pracowników (45\%). 


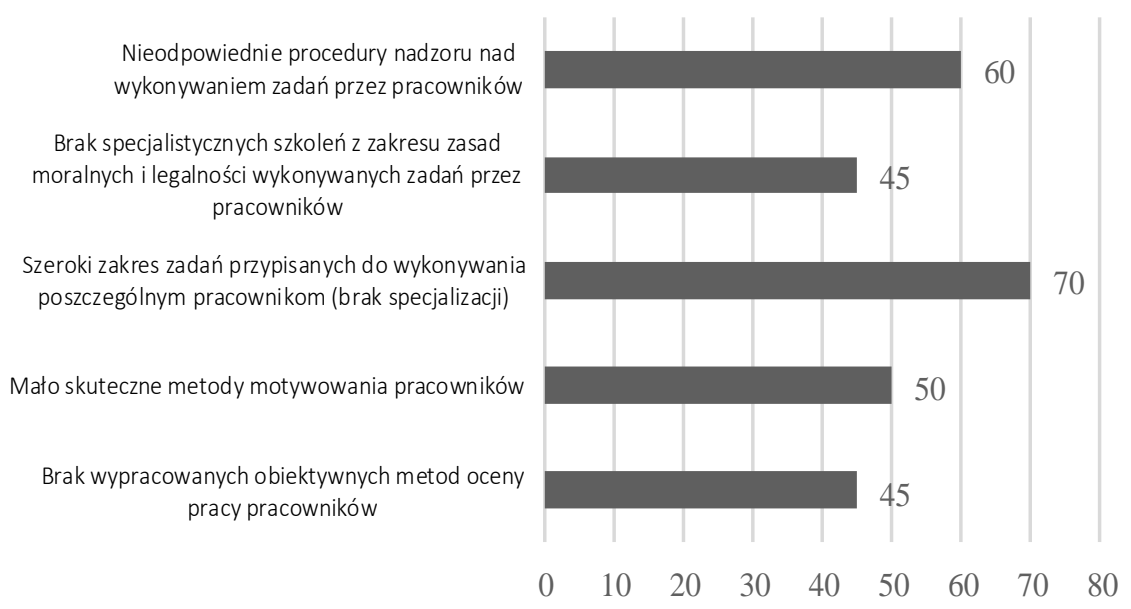

Rys. 3. Czynniki wywierające istotny wpływ na nieetyczne zachowanie urzędników samorządowych w zakresie wykonywania zadań publicznych - zdaniem ankietowanych pracowników (\% wskazań)

W procesie funkcjonowania administracji samorządowej szczególnie istotne pozostają normy i zasady moralne bezpośrednio wskazane w EKDA. Obowiązki pracowników administracji publicznej wiążą się z nieustannym kontaktem z obywatelami. $Z$ tego też względu na tej grupie zawodowej spoczywa ogromna odpowiedzialność za bezpośrednią realizację wspólnego dobra. Aby obywatele mieli zaufanie do służby publicznej, musi być ona w swych działaniach kompetentna zarówno merytorycznie, jak i moralnie. Właśnie dlatego nierealne jest istnienie służby publicznej bez zasad, moralności czy etycznych ocen. Przestrzeganie i wyznawanie przez grupę urzędników publicznych wspólnych wartości wpływa na jej konsolidację i pozytywny odbiór w społeczeństwie. Zdecydowana większość samorządów lokalnych, $\mathrm{z}$ racji pełnionych przez siebie funkcji obywatelskich, stworzyła własne, wewnętrzne kodeksy etyczne. W zapisach tych zawarty został katalog etycznych zachowań oraz dopuszczalnych standardów, którymi każdy pracownik administracji publicznej powinien się kierować. Wprowadzenie tego typu kodeksów wpłynęło pozytywnie na harmonizację w wielu postępowaniach, a także ułatwiło orientację na główny cel administracji - realizację dobra wspólnego.

Podsumowując, można stwierdzić, że urzędnik wykonujący zadania rzetelnie i w zgodzie z zasadami moralnymi zawsze funkcjonuje w świadomości obywatela jako ten, który stoi na straży praworządności. To on jest siłą napędową administracji i to za jego sprawą działania administracyjne realizowane są sprawnie, fachowo, rzetelnie i sprawiedliwie. Występują jednak odstępstwa od tych zasad, które mogą wywoływać w administracji samorządowej zjawiska patologiczne, określane jako przestępstwa urzędnicze. Do najczęściej występujących patologii 
można zaliczyć: nadużycie władzy, korupcję, umyślne niedopełnienie obowiązków służbowych, wykonanie polecenia prowadzącego do popełnienia przestępstwa, nieprzestrzeganie przepisów dotyczących ochrony informacji niejawnych, ochrony danych osobowych, poświadczenie nieprawdy, nieprawidłowości przy zamówieniach publicznych. Jednym $\mathrm{z}$ głównych przestępstw urzędniczych jest łapownictwo. Kolejnym przestępstwem jest protekcjonizm, który polega na podjęciu się pośrednictwa w załatwieniu sprawy w zamian za korzyść majątkową lub osobistą albo jej obietnicę, powołując się na wpływy w instytucji państwowej lub samorządowej.

Do przestępstw, które mogą zostać popełnione przez urzędników administracji publicznej, można zaliczyć również te przeciwko ochronie informacji niejawnej, a także przestępstwo tzw. fałszu intelektualnego dokumentu, charakteryzujące się tym, że funkcjonariusz publiczny lub inna osoba uprawniona do wystawienia dokumentu poświadcza w nim nieprawdę co do okoliczności mającej znaczenie prawne.

\section{Podsumowanie}

Europejski Kodeks Dobrej Administracji stanowi uszczegółowienie prawa do dobrej administracji ustanowionego w art. 41 Karty Praw Podstawowych Unii Europejskiej. Zapisy EKDA stanowiące standardy dobrej praktyki administracyjnej w organach i instytucjach Unii Europejskiej, mające charakter „miękkiego prawa", stały się w Europie istotnym dokumentem, który powinien przyczynić się do podniesienia poziomu pracy urzędników i wzmocnienia ochrony prawa do dobrej administracji. Należy podkreślić, że działania urzędnika administracji, zarówno polskiej, jak i unijnej, nie podlegają jedynie ocenie polegającej na sprawdzeniu zgodności z obowiązującymi przepisami prawa, gdyż taka ocena byłaby niepełna. Dla realizacji prawa jednostki do dobrej administracji szczególnie istotne pozostają zasady moralne, tj. życzliwe i uprzejme odnoszenia się do osób, gotowość świadczenia pomocy, wskazywania zainteresowanym właściwych organów i funkcjonariuszy, rozsądne i szybkie postępowanie niezależnie od źródła nakazanych czy postulowanych zachowań. Standardy te wskazuje EKDA. Dokument ten, poza obowiązującymi regulacjami ustawowymi określającymi procedury postępowania pracowników samorządowych, pełni istotną rolę w dążeniu do dobrej administracji i uzupełnia regulacje ustawowe w zakresie postępowania administracyjnego.

\section{Bibliografia}

Bugdol, W. (2008). Zarządzanie jakościa w urzędach administracji publicznej teoria i praktyka. Warszawa: Wydawnictwo Difin. 
Czajka, Z. (2012). Zarzadzanie zasobami ludzkimi w administracji publicznej. Warszawa: Wydawnictwo Instytutu Pracy i Spraw Socjalnych.

Izdebski, H., \& Kulesza, M. (2004). Administracja publiczna. Zagadnienia ogólne. Warszawa: Wydawnictwo Liber.

Izdebski, H. (2010). Kodyfikacja etyki w służbie publicznej - doświadczenia Kodeksu Etyki Służby Cywilnej. Diametros, 25, 20-29.

Kowalczyk, L. (2008). Współczesne zarządzanie publiczne jako wynik procesu zmian z podejściu do administracji publicznej. Zeszyty Naukowe Wałbrzyskiej Wyższej Szkoły Zarządzania i Prawa, 11(1), 4-14.

Lipowicz, I. (2005). Prawo obywatela do dobrej administracji, referat z konferencji „Dobra Administracja” posiedzenie Kolegium Najwyższej Izby Kontroli.

Modzelewski, P. (2012). System zarzadzania jakościa a skuteczność i efektywność administracji samorzadowej. Warszawa: Wydawnictwo CeDeWu.

Suchodolski, B. (2012). Kodeks etyczny jako narzędzie służące do podnoszenia jakości usług administracji publicznej. Zeszyty Naukowe Uniwersytetu Przyrodniczo-Humanistycznego w Siedlcach, 21(94), 153-169.

\section{Akty prawne}

Decyzja Parlamentu Europejskiego w sprawie Kodeksu Dobrej Praktyki Administracyjnej. Dz.Urz. UE 201.C285/3 z 29.09.2011.

Karta Praw Podstawowych Unii Europejskiej. Dz.Urz. UE 2016 C 202.

Konstytucja Rzeczypospolitej Polskiej z dnia 2 kwietnia 1997 r. uchwalona przez Zgromadzenie Narodowe w dniu 2 kwietnia 1997 r., przyjęta przez Naród w referendum konstytucyjnym w dniu 25 maja 1997 r., podpisana przez Prezydenta Rzeczypospolitej Polskiej w dniu 16 lipca 1997 r. Dz.U. 1997, nr 78, poz. 483.

Rozporządzenie Parlamentu Europejskiego i Rady (UE) 2016/679 z dnia 27 kwietnia 2016 r. w sprawie ochrony osób fizycznych w związku z przetwarzaniem danych osobowych i w sprawie swobodnego przepływu takich danych oraz uchylenia dyrektywy 95/46/WE (ogólne rozporządzenie o ochronie danych).

Ustawa z dnia 14 czerwca 1960 r. Kodeks postępowania administracyjnego. Dz.U. 2017, poz. 1257.

Ustawa z dnia 29 sierpnia 1997 r. Ordynacja podatkowa. Dz.U. 2017, poz. 201.

Zarządzenie nr 70 Prezesa Rady Ministrów z dnia 6 października 2011 r. w sprawie wytycznych przestrzegania zasad służby cywilnej oraz w sprawie zasad etyki korpusu służby cywilne. M.P. 2011, nr 93 poz. 953. 